\title{
Education in the new era should focus on strengthening moral education and cultivating people's overall development as the key direction
}

\author{
Hanyang ${ }^{1, a}$, Tangyanling $2, b,{ }^{*}$ \\ ${ }^{1}$ State Grid of China Technology, Ji'nan, Shandong 250000, China \\ 2 State Grid of China Technology, Ji'nan, Shandong 250000, China \\ ahy19870604@163.com, b295968087@qq.com
}

Keywords: Education in the new era, moral education, people's overall development.

\begin{abstract}
In the new era, educational work should pay more attention to the moral education of people and the overall development of people. china has an excellent traditional culture, and we have made remarkable achievements in the decades of reform and opening up. In the face of the problems in the current education work, we have sufficient confidence to continue to improve. from three points of view, this paper discusses the direction of strengthening moral education and the people's overall development. It is to establish self-confidence in socialist education with Chinese characteristics, to link youth training with the requirements of the new era, and to focus on the construction of modern teaching staff.
\end{abstract}

\section{Introduction}

A new era of propulsion system to strengthen the moral education, cultivate all-round development work, is to implement the party's education policy, promot the inevitable requirement of fairness of education, and strengthen the implementation of moral education, cultivate all-round development work, but also is an important measure to meet the good needs of the people in the new era. 2018 is the year of carrying out the nineteen spirit of the party. It is the year of education to carry out the "pen of Endeavour", how to further strengthen moral education, cultivate all-round development work, grasp the direction, clear thinking, i will talk about that from three points.

\section{Article subject}

\subsection{We should build up the confidence in the education of socialism with Chinese characteristics in the new era.}

When inspecting University of Science \& Technology China, general secretary Xi Jinping pointed out that we have confidence in China's construction of world-class universities and training of world-class talents.in order to do a good job in the new era of education, especially to carry out the moral education in depth and train people to develop education in an all-round way, we must firmly establish the confidence in the education of socialism with Chinese characteristics in the new era.

Chinese culture has a long history. In the long river of history, there are many educational people, such as Confucius and Lao Tzu. The traditional ethical and moral ideas, such as Confucianism, Mohism, Taoism and Legalists, are the essence of Chinese traditional education, and the foundation of the Chinese national fine moral tradition has been built. At the same time, the moral education is strengthened and the people are trained for the new generation. Comprehensive development provides strong cultural support. On the other hand, in terms of the continuous promotion and improvement of education, our country has been exploring and practicing the socialist education, and has made continuous efforts to achieve a miracle in the cause of education. At the sixteenth World Conference on comparative education, Chen Baosheng, Minister of education, pointed out that China has built the largest education system in the world, improved the education fairness and quality obviously, guaranteed the right of hundreds of millions of people to be educated, greatly improved 
the quality of the whole nation and promoted the economic and social development. All these facts prove that we have the ability to push forward education.

In the new era, we still have many unbalanced problems in implementing the basic task of strengthening moral education and cultivating people's overall development. For example, the phenomenon of the current heavy intelligence and light moral education is relatively common, the awareness and ability of teachers needs to be strengthened, and the construction of teachers and moral teachers has not been paid enough attention. Faced with these problems, we must still firmly establish self-confidence in socialist education and continue to uphold the fine tradition of hard struggle. The achievements of our education in the past and the natural traditional cultural advantages of our country have given us enough confidence to promote the moral education in the new era of the new era, to cultivate the people's overall development work, to actively meet new challenges and to grasp the new opportunities with strength.

\section{2 we should pay attention to the cultivation of the socialist core values of the young students, set up four confidence and emphasize the edification of the Chinese traditional virtues.}

The young generation is the main force of the new times. The young generation has the ideal, the pursuit and the responsibility, and the great rejuvenation of the Chinese famous people has a steady stream of youth. Since the eighteen Congress of the party, general secretary Xi Jinping has not only once given expectations and demands to young people on important occasions both at home and abroad: when talking with outstanding youth representatives from all walks of life, general secretary $\mathrm{Xi}$ Jinping put forward five demands on young people, pointing out that the young people must firmly believe in their ideals, must have excellent skills and must be brave. Youth must be constantly innovating and full of vitality, in the speech at the symposium between teachers and students at the Peking University, general secretary Xi Jinping put forward four demands on the values of youth, demanding that young people should study diligently, cultivate morality, distinguish and be true, and president Xi Jinping pointed out in the nineteen major reports, "The young generation has ideals, skills and responsibilities. From $t$ these speeches, we have seen the eager expectations of the country for the youth, and also give inspiration to the promotion of moral education and the development of the overall development of the people. In the new era, we must pay attention to the ideal and belief education of the youth, the education of the socialist core values and the Chinese excellent traditional culture education. To shoulder the responsibility and mission of strengthening moral education and cultivating all-round development of human beings, we should pay more attention to the sense of responsibility of youth and strengthen the ideals and beliefs of youth. Facing the impact of multiculturalism, information and world flattening, various forms of culture will undoubtedly affect the value choice of young people. The majority of young people should have great ideals, have firm beliefs, inherit the fine tradition of hard struggle, overcome all kinds of temptations with firm faith.,"make them become the inheritor of the traditional Chinese virtues, the propagator of the new wind of the times, the advocate of the fine fashion, the practitioner of the socialist concept of honor and Disgrace" ${ }^{[1]}$.

To shoulder the responsibility and mission of strengthening moral education and fostering all-round development of human beings, we should pay attention to training four self-confidences of young students. In the new era, we should pay more attention to cultivate the young people to build up the Chinese characteristic socialist culture self-confidence and carry forward the traditional culture of the Chinese nation, so that the young people can examine the other history and culture of the world rationally. In the new era, we should pay attention to the training of the young people to establish the theory of socialism with Chinese characteristics, and adhere to the idea of armed youth with the ideology of socialism with Chinese characteristics in the new era of Xi Jinping, to guide the action of youth, and to build up a strong spiritual pillar of the young people in the new era with the scientific theory of the party. In the new era, we should pay more attention to cultivating the confidence of the young people to set up the socialist road with Chinese characteristics, and firmly believe that the new era is the right way for the young people to grow up only under the leadership of the Communist Party of China and unswervingly take the Chinese road of the people. It is necessary to link the youth dream 
with the Chinese dream together. In the new era, we should pay more attention to training the youth to build up the socialist system with Chinese characteristics, firmly establish the socialist system consciousness with Chinese characteristics, maintain the system consciously, and do a good job of the successors of the construction of socialism with Chinese characteristics.

To shoulder the responsibility and mission of strengthening moral education and fostering all-round development of human beings, we should pay attention to the edification of Chinese traditional virtues to young people. Dante, a Italy poet, once said, "a man with an unsound knowledge can make up for it with morality, but a man with a bad morality is hard to make up for it." In the face of the educational situation of the original wisdom and light virtue, we should give full play to the advantages of Chinese traditional virtues, lead the young students to set up a correct outlook on life and values, cultivate the good habits of the students by drawing the essence of the traditional Chinese virtues, and make them know the good moral quality. It will benefit from lifelong development and eventually become excellent talents with both ability and integrity through comprehensive development.

\section{3 we should pay attention to the construction of teachers' ethics.}

The nineteen major reports of the party clearly put forward "strengthening the construction of teachers' ethics, cultivating high-quality teachers, and advocating the whole society respecting teachers." Correspondingly, the quality of teachers directly affects the enhancement of moral education and the realization of the goal of all-round development of human beings. The dictionary of education points out that the quality of teachers is the basic condition for teachers to fulfill their educational and teaching tasks ${ }^{[2]}$. Xie Anbang believes that "the quality of teachers includes professional ethics, educational ideas, knowledge, ability, and teachers' personality traits or personality traits" ${ }^{13]}$.

In the new era, it takes on the responsibility and mission of strengthening moral education and cultivating the all-round development of human beings. The system promotes the strengthening of moral education and the all-round development of human beings. It can not be separated from a high quality teacher with noble morality, exquisite business, reasonable structure and full vitality. The general secretary of Xi Jinping emphasizes that teachers' words and deeds are highly guided and demonstrative for young students. As teachers, it is necessary to stand upright, learn from virtue and teach by virtue at any time. Teachers' profession determines that teachers must be moral and noble people. Teachers are a mirror of students' moral cultivation. As a teacher, it is far from enough to do a good job of preaching and confusion. They should also pay more attention to the improvement of their personality quality and influence young students with their noble human Charm. In recent years, many teachers' ethics and unharmonious voices have appeared, and some teachers have lost their basic professional ethics, lost the cause and sense of responsibility that teachers should have, resulting in bad social influence and seriously damaged the overall image of the people. Morality is the soul of teachers. Teachers' morality is a direct reflection of teachers' personality. Without high-quality teachers, there will be no high-quality education, and it is impossible to promote moral education and cultivate all-round development.

In the new era, it is an important measure to carry out the nineteen major party's overall development of education, and to carry out the responsibility and mission of strengthening the moral education and cultivating the all-round development of the people. It is also the fundamental guarantee for the people's satisfactory education. Young students are the main force of the Chinese dream of the great rejuvenation of the Chinese nation. Teachers are the dream makers who build this "dream team". Today, it is important to promote moral education and train people's overall development as a system. Unswervingly firmly "four confidence", closely surrounding the strengthening of moral education, cultivating the fundamental task of all-round development of people, building a good moral, professional, loyal and modern teachers to the party, and constantly cultivate the "four" young people with ideal faith, moral sentiment, real learning and benevolence. At the same time, students have contributed to the continuous deepening of moral education and the 
development of the overall development of the people, as well as a contribution to the continuous deepening of educational reform and the consolidation of the education power.

\section{References}

[1] Huang Yan, dawn. The new connotation, new mission and new requirement of College Students' Ideological and political education, [J]. Chinese higher education, 2013, (8).

[2] Gu Mingyuan. Dictionary of Education (Volume 2) Z. Shanghai: Shanghai science and Education Press, 1990.

[3] Xie Anbang, Zhu Yubo. An analysis of the category and structure of teachers' quality [J]. Teacher education research, 2007 (02): 1 - 5. 